\title{
Technology and Adult Students In Higher Education: A Review of the Literature
}

\author{
Clayn Lambert, Luke Erickson, Ali Alhramelah, Derick Rhoton, \\ Robin Lindbeck, Dotty Sammons \\ Idaho State University
}

\begin{abstract}
Adult learners are becoming more common in institutions of higher education. These learners often bring with them experiences and expectations that can significantly affect their educational needs, progress and activity in the classroom. A review of the literature suggests instructors in higher educational settings need to review their current teaching methodologies in light of the increase in enrollment of these types of students. Specifically, pedagogical, or instructorcentered, approaches tend to be less effective in meeting the needs of adult learners. Additionally, faculty must change their perceptions about the presence and utilization of instructional technologies in meeting student needs, especially those of adults. Instructors must consider how technology can influence the development and application of andragogy in the classroom to assist adult learners.
\end{abstract}

Keywords: Adult learners; andragogy; technology integration; higher education

\section{Introduction}

The demographics of students attending institutions of higher education in the United States are changing. From 2000-2009, these institutions have seen a 30\% increase in enrollment of students aged 25 and over, with these groups making up $39 \%-42 \%$ of the total enrollment in these institutions (Snyder \& Dillow, 2012). These students form a distinct population in that they often bring rich personal and employment experiences to the classroom, may struggle to support multiple roles and responsibilities above and beyond those of traditional learners, and can require significant adjustments in terms of their learning styles, needs, and abilities (Baptista, 2013; Ross-Gordon, 2011).

At the same time, there has been an incredible expansion in the area of information and communications technology (Radford, 2011). This growth in technology is changing the nature of higher education. Educators are feeling more and more pressure to provide educational content and teaching methods that keep pace with ongoing scientific and technical progress. Faculty, especially in higher educational institutions, must adapt to employ technology effectively to deliver content for students, whether on campus or at a distance. The question to be asked is: How are faculty at institutions of higher education providing instruction that reflects the educational experiences and expectations such changes in technology bring with them? 
To optimize learners' experience and the efficacy of learning outcomes, instructors need to consider how technology can offer approaches better suited to adult learning. Critical considerations about the potential influence of technology on educational design and implementation may provide teachers in higher education settings with the opportunity to modify their approaches to teaching and learning in novel ways.

This literature review will examine the published literature on the use of technology in higher education settings as it relates to adult learners, summarize and discuss the findings contained in that literature, and finally present recommendations on whether additional research is needed. In addition, the article will offer suggestions for possible critical application and integration models.

\section{Methodology}

Searches for peer-reviewed journal articles and dissertations were conducted using primarily EBSCOhost, Google Scholar, and Academic Search Premier. All searches were limited to journal articles, published in English. Database searches took place between October 2013 and December 2013. Supplemental searches were also conducted in April 2014.

An initial review of literature on adult learning in higher education settings was conducted using keywords such as adult learner, adult education, and adult student, connected by Boolean operators with andragogy, higher education, college, and university. The review of literature regarding the use of technology by faculty in higher education settings used the terms role of technology in higher education, using technology in higher education, and technological tools. The final section of the review, considering possible methods and practices to address the gaps between the needs of adult learners and faculty technology use, centered on searches using keyword terms andragogy, pedagogy, technology, and adult education.

The primary criterion used for inclusion and exclusion in the review was the publication date of the source. For the most part, only articles published after 2009 were included in the review, though this criterion was adjusted in some cases to include relevant work. This date was selected to reflect current attitudes and practices related to the instruction of adult learners, as well as recent practices and perceptions of technology in higher education settings. With the exception of the section regarding rollout dates on social media, only articles published in peer-reviewed sources were considered for inclusion in the review.

\section{Findings}

Foundational to the discussion of the current state of instructional practice in institutions of higher education is a consideration of one of the primary consumer groups of such instruction - students identified as adult learners. This section will consider what the literature establishes about adult learners in higher educational settings. 


\section{Challenges in defining adult learners}

Defining who fits into the scope of adult learners can be problematic, as there are few traits identified within the literature that concur on how to describe such a target population demographic. Questions arise as to whether the qualification for consideration to belong to this group rest solely upon the age of the learner, or if the term adult is more a reflection of the participant's mental, cultural, or educational maturity. Most adult learners can be highly segmented in terms of their responsibilities within learning environments; therefore, an honest understanding of adult learners is critical for their success (Scanlon, 2009).

Common traits of adult learners. Adult learners are most often described as individuals identified as non-traditional: students over the age of 25 or who lie outside the traditional conception of a college student (Kenner \& Winnerman, 2011; Plageman, 2011; Hines, 2006). Indeed, the title of adult learning tended to refer exclusively to students who were not considered traditional college students. When referring to students as being non-traditional, the literature tended to rely on identifying individuals who fit into one or more of several common categories of students: entry to college delayed by at least one year following high school, age older than 25, having dependents, being a single parent, being employed part or full time, being financially independent, attending part time, not having a high school diploma, and possessing life or work experience external to educational institutions (Baptista, 2013; Kenner \& Winnerman, 2011; Plageman, 2011; Ross-Gordon, 2011; Hines, 2006).

Ross-Gordon (2011) delves into this question in more depth, coming to the conclusion that what was once called non-traditional is slowly metamorphosing into a new normal, with the implicit assertion that many institutions of higher education are woefully underprepared to meet the needs and interests of the individuals who fit into these demographic categories (Chavez, 2006; Falasca, 2011). Indeed, throughout the literature, the title of adult learning tended to emphasize students who were not traditional college students. The literature did not provide any clarifications on why all adult students who fit this description were still considered non-traditional; in fact, Chan (2009) argues that additional research and review is warranted to examine this gap in the literature.

Implications of adult learning traits. Marschall and Davis (2012) observed that adult learners need opportunities to harness the depth of their life experience to increase their abilities to perform critical thinking, a highly valued skill in higher education settings. Hussain concurred with this position, stating:

Adults are assumed to be mature intellectually and socially having their own concept and experience of life and learning formally or informally. They play different roles in the society. Therefore, they need to be treated as adults in instructional process (Hussain, 2013, p 124).

Johnson, Wisniewski, Kuhlemeyer, Isaacs, and Krzykowski (2012) take this point even further by making the observation that faculty, as adult learners as well as adult educators, need to be aware that their own (current) learning experiences should mirror 
the experiences of their students; orientation in terms of professional development should focus more on faculty learning than faculty teaching. Moore (2010) also adds that adults tend to have very established preferences as to what their learning styles are and that, to be effective, instructors must prove amenable to adapting their teaching to accommodate those styles. Paraskevas and Wicken's (2003) studies about law school instructional methods also showed that educational practices can only work when instructors are sensitive to adult students and their reactions to these teaching methods.

\section{Andragogy}

Any examination of the literature of adult education and learning could not be considered complete without a discussion of Malcolm Knowles' work on andragogy (1970; 1973; 1990). While Knowles acknowledged he was not responsible for the creation of the term andragogy, he wrote many of the central texts that initiated serious scholarly work in this area. Knowles initially described andragogy as "the science and art of educating adults" (1970, p. 43), taking pains to distinguish it from the work taking place with the education of children, which he defined as pedagogy. Pew defines pedagogical practices as what occurs when "[. . .] teachers assume responsibility for making decisions about what is learned, and how and when something will be learned. It is teacher-directed or teacher-centered" (200 7, p. 17). The Greek etymology of pedagogy, from пaı $\delta a \gamma \omega \gamma \varepsilon \dot{\varepsilon} \omega$, implies that this model of instruction was intended for children.

It was this separation of the two models based on solely on the age of the learner that has created much of the confusion around the meaning and application of andragogy in current settings. Over time, the use of the term adult became almost permanently interchangeable with andragogy, which is somewhat misleading. Even Knowles himself revised his original position on andragogy to reflect that the central principles of the model were not limited by the age of the learner (1980). Instead, he advocated that the educational needs and preparation of each student needed to be assessed and addressed, rather than simply default all educational practices to the more prescriptive format of pedagogical theory $(1973 ; 1980)$.

Samaroo, Cooper, and Green (2013) assert that andragogy is not intended to replace pedagogy, but to meant to parallel or complement a wide variety in educational practices in the classroom. Henschke (2011), a close associate of Knowles, also emphasized that the research regarding andragogy should move beyond Knowles' work to acknowledge more recent work in the area and adaptations of the work to reflect more modern thinking.

Classical versus modern andragogical paradigms. More recently, andragogy seems to be moving away from a teaching approach oriented to a specific age group towards other models that emphasize the role of the student in the teaching process (Henschke, 2010; Rodrigues, 2012). This new version of andragogy focuses on learnercentered teaching methods, as opposed to the instructor-centered practices associated with pedagogy (Halx, 2010; Taylor \& Kroth, 2009a; Taylor \& Kroth, 2009b).

Bass (2012) observed that adult learners tend to show that Piaget's (1968) formal 
operational mode does not adequately reflect the learning styles or needs of adults. Bedi (2004) shows that andragogy moves beyond Piaget's work because it "facilitates the understanding of student behaviour in the teaching relationship, provides a theoretical reason for teaching behaviour and is a guiding philosophy for how to manage the learning environment towards an effective outcome" (p. 97), a perspective supported by Ausburn (2004). This reaffirms Henschke's argument (2011) that the original position of andragogy as a description of the nature of adults in educational settings does not reflect how andragogy is represented in more recent articles: a model of learner-centered thinking and a much more pragmatic model for educational design.

Andragogy and higher education. As institutions that focus on dealing with students after secondary education, colleges and universities are uniquely situated to consider the impact and importance of andragogy on adult learning communities. Halx (2010) builds on this perception by demonstrating that relying solely on traditional pedagogical practices will prevent college students from advancing into more mature and advanced thinking processes; andragogy should be used much more frequently. Yannuzzi (2009) also noted that the need for self-analysis, self-criticism, and openness to the ideas of others can require significant re-evaluation of teaching methods, objectives, and the expectations faculty can have of their students.

The growth of online education offers specific opportunities for implementing andragogy in higher education. Cercone (2008) examines how online learning can facilitate aspects of learning that cater to the common learning preferences of adult learners, such as self-direction, need for applicability and relevance, and the opportunity to develop community among learners. This need for community is also of particular interest for incoming students, as noted by Feiertag and Berge (2008).

Challenges to andragogy as a theory. While much of the literature is positive in terms of the role andragogy can play in adult learning, it is not without its critics and conflicts. As Minter (2011) stressed, there is little to no agreement on universal theories that apply to all students in higher education settings, making it difficult for faculty with little experience in the area to know what theories or practices to implement or how to do so effectively.

Another criticism of andragogy is the lack of empirical studies to support Knowles' claims about the concept. Studies (Taylor \& Kroth, 2009a; Taylor \& Kroth, 2009b; Holton, Wilson \& Bates, 2009) assert that instruments can be developed to collect that data, although wide scale implementations and testing of these models are still pending. However, DiBiase and Kidwai (2010) do provide evidence in a quasi-experimental review of adult learners and their performance in online classes that pedagogical practices and activities were less effective for adult learners than similar activities redesigned using andragogical principles.

Challenges to andragogy in application. Strong, Harder, and Carter (2010) demonstrated that changing teaching practices to include more andragogical approaches can be difficult, even if training and resources are provided to instructors to facilitate a 
transition to a more learner-centered model. Participants in the study noted that time, funding, and other obligations were obstacles to the implementation of andragogical teaching practices; the authors also noted that personal preferences and organizational barriers also limited application of andragogical practices (Strong, Harder \& Cartwell, 2010). Pew (2007) also asserted that misunderstandings about the distinctions between what makes instruction pedagogical or andragogical can frustrate efforts to address the needs of adult learners. Additionally, some instructors who are aware these principles can still misapply them in classroom settings (Pew, 2007, p. 19). This lack of understanding about the implications or applications of pedagogical or andragogical models was also a central theme in Donavant (2009).

Chan (2010) supported this general critique of andragogy, asserting that instructors often use pedagogical methods because that was how they were taught, but history is not necessarily a compelling critical justification for educational design or delivery. Victor (2004) however, challenges this assertion, citing the qualitative findings of a study on adult learners taking a course on andragogical theory, who identified that their own teaching methods outside of the class tended to follow the same theories that were covered in the course.

\section{Technology and Education}

Development of social media. At the end of the $20^{\text {th }}$ and beginning of the $21^{\text {st }}$ century, social media were beginning to coalesce into what is now commonly referred to as Web 2.0. Many of the tools commonly associated with social media were on the cusp of being invented, such as Myspace in 2003 (Bennett, 2008), Facebook in 2004 (Yadav, 2006), YouTube in 2005 (Dickey, 2013), and Twitter in 2007 (Meyer, 2011). Since the turn of the new millennium, technological devices, software programs, and the influence of the Internet on educational practice have evolved substantially.

Presence of technology in higher education. The environment of higher education is also evolving. Many factors are currently in play: rising costs and shrinking budgets (Brock, 2010; Harris \& Goldrick-Rab, 2010, December; Zusman, 2005), as well as an increasing need for distance education (Hoskins, 2011; Lei \& Govra, 2010; Moore, Dickson-Deane \& Galyen, 2011). These changes will create a worldwide need for a reexamination of the way in which education is delivered to students (Wagner, Hassanein \& Head, 2008). Many institutions are turning to an increased reliance on e-learning, thereby creating new opportunities for both the educational institutions themselves and their students (Wagner, Hassanein \& Head, 2008).

Most students are not only comfortable with using technology in higher education classrooms; they also expect their instructors to use technology in their courses (Kyei-Blankson, Keengwe \& Blankson, 2009). For instructors to integrate technology successfully, they must remain current with available technology options and programs (Taylor, 2006). 
Rutherford (2010) points out that education can be enhanced by the use of social media to strengthen the relationship between students, classmates, and instructors. Therefore, teachers may find uses for social media tools in the teaching process because students can access the information from laptops and mobile devices during class, as well as before and after class. With this in mind, new technology tools and programs can also be an important element in the future of distance education, opening doors of educational opportunity students could not access before. By using social media tools in distance education, students can have a positive and effective relationship with their instructors, the materials, and their peers. These findings were also borne out by Exter, Korkmaz, Harlin, and Bichelmeyer, (2009) during their investigation of the role of technology in higher education, specifically in distance learning.

Challenges in integrating technologies in higher education. Teaching with technology is a complex process that involves matching content, delivery, and device with the oversight of the instructor (Keengewe, Onchwari \& Wachira, 2008). Furthermore, there is a lack of understanding and consensus on how to combine different technology tools with other learning tools (Woodbridge, 2004). Effective technology integration is sporadic. When it is implemented successfully, it involves students constructing their own learning using both hardware and software tools and allows for student-centered approaches for both teacher and student (Woodbridge, 2004); this is the essence of andragogy understood as student-centered learning.

Assessing technology integration and efficacy. The successful implementation of e-learning in higher education may need a change of perception by both students and teachers (Liaw \& Huang, 2013; Lin, 2012; Rosenbaum, 2012). Jung (2011) identified seven dimensions that may be considered in evaluation the quality of e-learning. These dimensions include interaction, staff support, institutional quality assurance mechanisms, institutional credibility, learner support, information, as well as publicity and learning tasks. Jung's 2011 study demonstrated that the seven-factor model is a good fit for the observed data from online learners; all seven dimensions are important in evaluating the quality of e-learning from the learner's perspective.

Taking a different approach, Kirkwood (2009) examined variance between the potential and actual impact of e-learning on learning and teaching in higher education. He also posited that the use of information and communication technologies does not, in itself, result in improved educational outcomes and ways of working. However, various contextual factors exert greater influence upon what and how students learn. Kirkwood also suggested that institutions of higher education need to focus evaluation of teaching and assessment practices on e-learning practices to better understand the impact e-learning has on students' experiences of learning.

Technology use and the future of higher education. The implementation of e-learning in higher education has the potential to create more opportunities and raise the quality of education for a greater number of students (Basham, Smeltzer \& Pianfetti, 2013; Renes \& Strange, 2011; Veletsianos, 2011). In the future, e-learning in higher 
education can create environments in which learners receive more convenient and easier access to the educational process (Fisher \& Sadera, 2011; Keengwe, Schnellert, \& Mills, 2012).

Radford reports that from 2000 to 2008 the percentage of undergraduates enrolled in a distance education course or degree program increased (2011). The percentage of undergraduates enrolled in at least one e-learning class grew from eight percent to twenty percent, while the percentage of students enrolled in a degree program taught entirely through distance education doubled from two percent to four percent (Radford, 2011). These findings were supported by the Instructional Technology Council's survey (2010) which tracked the impact o e-learning at community colleges. The results indicated a robust growth pattern for distance education: campuses reported a twenty two percent increase for distance education enrollments.

\section{The Convergence of Technology with Andragogy}

Neiderhauser and Lindstrom (2006) assert that in many cases, it is no longer relevant to ask if technology is being used, but rather how it is being used. Several authors have also highlighted a general reluctance by educators to use technologies in new and innovative ways that improve student learning (Gandolfo, 1998; Papo, 2001; Redmond, 2011).

The most common practice by educators is simply to substitute new technology for traditional elements of a lecture (Gandolfo, 1998; Redmond, 2011). Papo points out that even in an online distance learning setting, a traditional lesson format is often followed. A relatively small but increasing number of educators are experiencing a paradigm shift, however, as face-to-face and distance education formats converge, allowing for a new look at andragogically driven approaches to learning employing new technologies (Papo, 2001).

Personal Knowledge Space. Most of the previously mentioned educational technologies promote new modalities of student-instructor and student-student interaction. Kooi (2008) suggested that new communication technologies are enabling traditional higher educational institutions to become more proficient at reaching diverse audiences. Traditional academic audiences are expanding to include more working professionals and lifelong learners who, through the use of these technologies, are better able to maintain professional and family commitments while engaging in higher educational programs and content. Kooi also suggested that the growing appeal of open educational resources, such as Massive Open Online Courses, to later life learners is leading to an expansion of andragogically centered, self-driven learning environments in many university settings (Kooi, 2008).

Manganello, Falsetti, Spalazzi, and Leo (2013) echoed this sentiment that self-driven learning is the hallmark of andragogy, and this type of learning is readily facilitated by effective technology integration. Specifically the authors suggested that the Personal Learning Environment (PLE) of adult learners should be structured in a way that (a) allows learners to easily select, organize and retrieve the resources they want, at their own pace 
and discretion; (b) streamlines the interaction process among learners; and (c) allows for trust and personal relationships among fellow students and the instructor(s) (p. 107). Cumulatively this type of learning environment is called the Personal Knowledge Space (PKS). The PKS is thought to allow for more dynamic adult learning both in terms of pace and content (Manganello, Falsetti, Spalazzi \& Leo, 2013).

The second and third elements of the PKS - streamlined interaction among learners and facilitation of trust building among learners and instructors - describe a common theme found throughout the literature on technology integration in higher education settings: it is vital that educational technologies support social interaction among learners and instructors (Bajt, 2011; Dye, 1998; Gandolfo, 1998; Hemmi, Bayne \& Land, 2009; Manganello, et al., 2013). The advent of Web 2.0 technologies has the potential to further transform traditional educational strategies by promoting interactions limited neither by time nor space (Bajt, 2011).

Digital natives and pedagogical shift. The Millennial generation in particular is perhaps the first generation to view online interaction and education as natural extensions of traditional interaction and education (Bajt, 2011). One of the great potential strategy changes that Web 2.0 introduces to higher education (and eventually to the workplace), is the idea of harnessing the collective intelligence of small and large groups of like-minded individuals (O'Reilly, 2006). Blogs, wikis, social networking sites like Facebook, simulation sites like Second Life, and untold numbers of additional tools allow unprecedented collaboration among learners, instructors, researchers, etc. (Hemmi, Bayne \& Land, 2009). Interestingly, such collaboration was part of the original plan for the World Wide Web (Berners-Lee, 1999). Human interaction is seen by many traditional educators as central to the educational process (Dye, 1998). Social technologies can help satisfy that need for interaction while maintaining all the advantages that educational technologies have to offer including unprecedented access to information, new means of learner engagement, and dynamic asynchronous and distance learning options, to name only a few.

The potential transformation of higher education by these social technologies is seen by some to be quite radical. While many higher education administrators acknowledge this potential and are making steps toward systematic technology implementation, most show a general reluctance to fully integrate technology and andragogical models of instruction (Hemmi, Bayne \& Land, 2009). Perhaps institutions of higher education are wise to move forward with caution because there are still many unanswered questions regarding social technology integration in higher educational settings. (Hemmi, Bayne \& Land, 2009).

Social technologies and associated educational possibilities have already begun to challenge the notions of effective knowledge generation and dissemination and the very structure of the traditional university (Hemmi, Bayne \& Land, 2009). To some, this potential andragogical shift can seem strange and troublesome, and significant research is still needed to explore the learning experiences and results of students fully engaging 
in these instructional practices (Barnett, 2005; Hemmi, Bayne \& Land, 2009).

Systematic integration of technology, instruction, and content. While digital technology in education presents both perceived opportunity and threats to higher educational institutions, many universities have already recognized that educational technology in some form is a necessity (Gandolfo, 1998). However, it is still relatively rare for educators to allow full integration of technology within the educational structure itself. Value is often placed on the mere use of technology, and not necessarily on its overall improvement of student learning. Often there are no methodologically driven goals among educators other than to use technology (Gandolfo, p. 28).

Ignoring the influence of technology on pedagogy or andragogy can be a long-term mistake because as Gandolfo (1998) suggested, "The only value of technology for instruction is if it enhances learning in ways that are not otherwise available" (pg. 31). Gandolfo further suggests that just because we can use technology in higher education does not mean that we should. However, Gandolfo concedes that educators often do not grasp the educational potential of a technology until they become familiar with it through hands-on investigation and trial experiences.

To strike this implied balance between short-term technology exploration, and long-term andragogical integration of technology, Persichitte (2013) suggests that educational leaders should take intentional action to manage educational technology and oversee a systematic shift from instructor-centered education to learner-centered and problemfocused methods (Persichitte, 2013; Watson \& Watson, 2013). Watson and Watson (2013) acknowledged the complexity of systemic change within institutions of higher education, with diverse and complex missions, processes, products, economic factors and administrative structures. This is all the more reason to approach such changes intentionally, rather than incidentally (Kinchin, 2012b; Watson \& Watson, 2013).

Kinchin (2012a) proposed that the traditional system of content driven curriculum development be replaced by a more balanced approach that equally considers the implications of pedagogy, technology and content on the student learning experience. The Technological Pedagogical Content Knowledge (TPACK) model is one proposed solution. This emerging model is defined as promoting "engagement with the rich problems of pedagogy, technology and content and their inter-relationships $\sqrt{\text { â }}$ seeking to construct new ways of seeing the world, and new approaches to using technology, in order to develop creative pedagogical solutions" (Koehler, et al, 2011, pg. 154). Other models of successful systematic technology integration with andragogy in higher educational settings will likely emerge as time progresses and necessity requires. The key question however, is whether higher educational institutions will proactively embrace such models, or instead simply tolerate incidental technology use within the classroom.

\section{Discussion}

Technology has been rapidly advancing over the last several decades, and its use is more commonplace than ever, particularly among younger students who are considered 
digital natives (Bajt, 2011; Wagner, Hassanein \& Head, 2008). Students who began their education as digital natives are beginning to arrive at institutions of higher education and may bring with them certain educational expectations (Bajt, 2011). Unfortunately, the literature indicates that many of these institutions are not fully prepared to meet students with these experiences, needs and expectations (Hemmi, Bayne \& Land, 2009). While some administrators of higher education institutions may view this change in educational needs as challenging, even insurmountable, others will view it as an opportunity to consider technology more fully in educational design and to appropriately modify approaches to teaching and learning (Gandolfo, 1998).

Many faculty have already recognized the potential of e-learning tools and have begun the process of implementing technology in the classroom (Innes, Mackay, and McCabe, 2006; Wagner, Hassanein \& Head, 2008). However, it is generally not at a concurrent pace with technology development (Kirkwood, 2009). An additional concern is that many educators simply substitute new technologies for old, but entirely miss the idea that e-learning technologies can transform learning itself (Gandolfo, 1998). It can actually change the relationships and interactions of both learners and instructors, and improve student learning (Kooi, 2008; Manganello, Falsetti, Spalazzi, and Leo, 2013)

Andragogy, a field of research on adult learning, focuses on learner centered teaching methods (Knowles, 1973; Knowles, 1980). While originally this research was defined by the age of the learner, it has now come to be viewed as a dynamic, self-driven method of learning that is more commonplace among mature learners (Halx, 2010, Taylor \& Kroth, 2009a; Taylor \& Kroth, 2009b). Andragogy involves using the years of experience that the learner brings to the table to provide a context for formal and informal processing of newly acquired knowledge (Halx, 2010). This context, when properly designed and supported can provide the learner with an exploratory learning environment in which self-driven learning can thrive (Kooi, 2008).

According to the literature, colleges and universities are uniquely situated to consider the impact and importance of andragogy on adult learning communities. Online learning can facilitate aspects of learning that cater to the common learning preferences of adult learners, such as self-direction, the need for applicability and relevance, and the opportunity to develop a community among like-minded learners (Cercone, 2008).

There is some criticism that not all students in higher education will learn optimally through andragogical approaches (Minter, 2001). There is also criticism that many instructors are challenged by or resistant to andragogical based learning methods and consequently may misapply the associated principles, if they use them at all (Pew, 2007). While there is research supporting andragogically-based learning, wide scale implementation and testing of andragogically-based models are still needed to determine the precise benefits and challenges of such learning.

While the aforementioned criticisms are valid, research indicates a growing demand for technological supported learning that provides dynamic navigation and social learning tools (Kooi, 2008). Manganello, Falsetti, Spalazzi \& Leo (2013) introduce the idea of a 
learning environment termed as Personal Knowledge Space (PKS), a technologically supported learning environment where the learner can explore and accomplish learning tasks through independent navigation and at their own pace. This type of learning provides entirely new roles for both learners and instructors (Manganello, Falsetti, Spalazzi, \& Leo, 2013)

Members of the digital generation view online social activity as a natural extension of their offline lives (Bajt, 2011). Online interaction and education is a way to overcome the naturally isolating aspects of online learning and instead make it even more social and collaborative than traditional learning approaches (Hemmi, Bayne, Land, 2009). Learners can now communicate and collaborate with like-minded learners, instructors, even professionals, and harness the collective intelligence and mentoring powers of these communities (O'Reilly, 2011). Such learning opportunities require instructors to abandon the content-driven course development paradigm and instead seek a more balanced approach that considers technology, pedagogy and content equally in course development (Gandolfo, 1998).

Some emerging models have already begun to consider how such a balanced approach may be implemented systematically among institutions of higher education (Kinchin, 2012a). The TPACK model is one such proposed model that promotes "engagement with the rich problems of pedagogy, technology and content and their inter-relationships [Vâ] seeking to construct new ways of seeing the world, and new approaches to using technology, in order to develop creative pedagogical solutions" (Koehler, et al, 2011, pg.154). More research is certainly needed on this and other models that address the balance of technology, instruction, and content in instructional design.

The research indicates, however, that institutions of higher education would be well served by embracing a systematic model of intentional technology integration with instruction. After all, of the potential crises and challenges that may face a university, a paramount danger is in becoming irrelevant to the very students these institutions serve. As younger generations mature and arrive at these institutions these students will likely expect dynamic technology integration with their higher educational instruction. The question is: which institutions will be ready to meet this need? 


\section{References}

Ausburn, L. J. (2004). Course design elements most valued by adult learners in blended online education environments: An American perspective. Educational Media International, 41(4), 327-337.

Bajt, S. K. (2011). Web 2.0 technologies: Applications for community colleges. New Directions For Community Colleges, 2011(154), 53-62

Baptista, A. V. (2013). Non-traditional adult students: Who are they and what are the implications for higher education?. Cypriot Journal of Educational Sciences, 8(2), 235-246.

Barnett, R. (2005). Recapturing the universal in the university. Educational Philosophy and Theory 37, 785-797.

Basham, J., Smeltzer, A. \& Pianfetti, E. (2013). An integrated framework used to increase preservice teacher NETS-T ability. Journal of Technology and Teacher Education, 257-276.

Bass, C. (2012). Learning theories \& their application to science instruction for adults. The American Biology Teacher, 74(6), 387-390.

Bedi, A. (2004). An andragogical approach to teaching styles. Education for Primary Care, 15(1), 93-97.

Bennett, A. (2008, August 15). "A place for friends" a history of myspace. Retrieved from http://www.randomhistory.com/2008/08/14 myspace.html

Berners-Lee, T. (1999). Weaving the Web: The Original Design and Ultimate Destiny of the World Wide Web by its Inventor. Harper: San Francisco.

Brock, T. (2010). Young adults and higher education: Barriers and breakthroughs to success. The Future of Children, 20(1), 109-132.

Cercone, K. (2008). Characteristics of adult learners with implications for online learning design. AACE Journal, 16(2), 137-159.

Chan, B. T. Y. (2009). Conceptualising Adult and Continuing Education Practice: Towards a framework for research. Australian Journal of Adult Learning, 49(1), 9-33.

Chan, S. (2010). Applications of andragogy in multi-disciplined teaching and learning. Journal of Adult Education, 39(2), 25-35.

Davis, H. S. (2012). Discussion as a bridge: Strategies that engage adolescent and adult learning styles in the postsecondary classroom. Journal of the Scholarship 
of Teaching and Learning, 13(1), 68-76.

DiBiase, D. \& Kidwai, K. (2010). Wasted on the young? Comparing the performance and attitudes of younger and older US adults in an online class on geographic information.Journal of Geography in Higher Education, 34(3), 299-326.

Dickey, M. (2013, February 16). How youtube went from startup to the world's largest video-sharing site. Retrieved from http://www.entrepreneur.com/ slideshow/225840

Donavant, B. W. (2009). The new, modern practice of adult education online instruction in a continuing professional education setting. Adult Education Quarterly, 59(3), 227-245.

Dye, N. S. (1998, June 8). "Virtual College: The End of the Campus?" Christian Science Monitor, p. 11.

Exter, M. E., Korkmaz, N., Harlin, N. M. \& Bichelmeyer, B. A. (2009). Sense of community within a fully online program. The Quarterly Review of Distance Education, 10(2), 177-194.

Falasca, M. (2011). Barriers to adult learning: Bridging the gap. Australian Journal of Adult Learning, 51(3), 583-590.

Feiertag, J. \& Berge, Z. L. (2008). Training generation N: how educators should approach the net generation. Education+ Training, 50(6), 457-464.

Fisher, C. \& Sadera, W. A. (2011). Comparing student learning and satisfaction between learning environments in continuing medical education. International Journal of Instructional Technology and Distance Learning, 8(5), 29-38.

Gandolfo, A. (1998). Brave new world? The challenge of technology to time-honored pedagogies and traditional structures. New Directions For Teaching \& Learning, 76(23).

Halx, M. D. (2010). Re-conceptualizing college and university teaching through the lens of adult education: regarding undergraduates as adults. Teaching in Higher Education, 15(5), 519-530.

Harris, D. N. \& Goldrick-Rab, S. (2010, December). The (Un) Productivity of american higher education: From 'cost disease' to cost-effectiveness. In Annual Meeting of the American Education Finance Association, Richmond, VA.

Hemmi, A. A., Bayne, S. S. \& Land, R. R. (2009). The appropriation and repurposing of social technologies in higher education. Journal Of Computer Assisted Learning, 25(1), 19-30 
Henschke, J. A. (2010). A Productive Decade of Andragogy's History and Philosophy 20002009. In V. Wang (Ed), Assessing and Evaluating Adult Learning in Career and Technical Education (pp 53-86). Hangzhou, China: Zhejiang University Press.

Henschke, J. A. (2011). Considerations regarding the future of andragogy. Adult Learning, 22(1), 34-37.

Hines III, M. T. (2006). A day at the SPA (Successful Practices of Andragogy): How to use the ELCC standards and adult learning theory to sustain a "self-asprincipal" voice in principal preparation students. Article of Best Practice 44.

Holton, E. F., Wilson, L. S. \& Bates, R. A. (2009). Toward development of a generalized instrument to measure andragogy. Human Resource Development Quarterly, 20(2), 169-193.

Hoskins, B. (2011). Demand, growth, and evolution. The Journal of Continuing Higher Education, 59(1), 57-60.

Hussain, I. (2013). A study of learners' reflection on andragogical skills of distance education tutors. International Journal of Instruction, 6(1).

Innes, A., Mackay, K. \& McCabe, L. (2006). Dementia studies online: Reflections on the opportunities and drawbacks of e-learning. Journal of Vocational Education \& Training, 58(3), 303-317. doi:10.1080/13636820600955567.

Instructional Technology Council. (2010). Distance education survey results Retrieved from http://www.itcnetwork.org/attachments/article/66/ ITCAnnualSurveyMarch2010Final.pdf

Johnson, T., Wisniewski, M. A., Kuhlemeyer, G., Isaacs, G. \& Krzykowski, J. (2012). Technology adoption in higher education: Overcoming anxiety through faculty bootcamp.Journal of Asynchronous Learning Networks, 16(2), 63-72.

Jung, I. (2011). The dimensions of e-learning quality: From the learner's perspective. Educational Technology Research and Development, 59(4), 445464.

Keengwe, J., Schnellert, G. \& Mills, C. (2012). Laptop initiative: Impact on instructional technology integration and student learning. Education and Information Technologies, 17(2), 137-146.

Keengwe, J., Onchwari, G. \& Wachira, P. (2008). The use of computer tools to support meaningful learning. AACE Journal, 16(1), 77-92.

Kenner, C. \& Weinerman, J. (2011). Adult learning theory: Applications to non-traditional college students. Journal of College Reading and Learning, 41(2), 87-96. 
Kinchin, I. (2012). Avoiding technology-enhanced non-learning. British Journal Of Educational Technology, 43(2), E43-E48.

Kinchin, I. M. (2012). Visualising knowledge structures of university teaching to relate pedagogic theory and academic practice. In J. Groccia, M. Al-Sudairi \& W. Buskist (Eds),Handbook of college and university teaching: a global perspective (pp. 314-332). Thousand Oaks, CA: Sage. In Press.

Kirkwood, A. (2009). E-Learning: You don't always get what you hope for. Technology, Pedagogy and Education, 18(2), 107-121.

Knowles, M. S. (1970). The modern practice of adult education (Vol. 41). New York: Association Press.

Knowles, M. S. (1973). The adult learner: A neglected species. Madison, WI: American Society for Training and Development.

Knowles, M. S. (1990). Andragogy in action. San Francisco, CA: Jossey-Bass.

Koehler, M. J., Mishra, P., Bouck, E. C., DeSchryver, M., Kereluik, K. \& Shin, T. S. (2011). Deep-play: developing TPACK for 21st century teachers. International Journal of Learning Technology, 6(2), pp. 146-163.

Kooi, B. R. (2008). Online education and the working professional: A University's responsibility?. Journal Of Applied Security Research, 3(3/4), 407.

Kyei-Blankson, L., Keengwe, J. \& Blankson, J. (2009). Faculty use and integration of technology in higher education. AACE Journal. 17 (3), pp. 199-213.

Lei, S. A. \& Govra, R. K. (2010). College distance education courses:

Evaluating benefits and costs from institutional, faculty, and students' perspectives. Education, 130(4).

Liaw, S. S. \& Huang, H. M. (2013). Perceived satisfaction, perceived usefulness and interactive learning environments as predictors to self-regulation in e-learning environments. Computers \& Education, 60(1), 14-24.

Lin, M. L. (2012). Students' motivation and attitudes in an online distance English course for placement year undergraduates in Taiwan (Doctoral dissertation, Queen's University Belfast).

Manganello, F., Falsetti, C., Spalazzi, L. \& Leo, T. (2013). PKS: An ontology-based learning construct for lifelong learners. Journal Of Educational Technology \& Society, 16(1), 104-117.

Marschall, S. \& Davis, C. (2012). A Conceptual framework for teaching critical reading to adult college students. Adult Learning, 23(2), 63-68. 
Mather, J. (2007, February 19) iMania. Ryerson Review of Journalism, (February 19, 2007) Retrieved from http://www.rri.ca/m4058/

Minter, R. L. (2011). The learning theory jungle. Journal of College Teaching \& Learning (TLC), 8(6), 7-16.

Moore, J. L., Dickson-Deane, C. \& Galyen, K. (2011). e-Learning, online learning, and distance learning environments: Are they the same?. The Internet and Higher Education, 14(2), 129-135.

Moore, K. (2010). The three-part harmony of adult learning, critical thinking, and decision-making. Journal of Adult Education, 39(1), 1-10.

Myers, C. (2011, July 15). 5 years ago today twitter launched to the public. Retrieved from http://thenextweb.com/twitter/2011/07/15/5-years-ago-today-twitterlaunched-to-the-public/

Neiderhauser, D. S. \& Lindstrom, D. L. (2006). Addressing the NETS for students through constructivist technology use in $\mathrm{K}-12$ classrooms. Journal of Educational Computing Research, 34(1), 91-128.

O’Reilly, T. “Web. 2.0 Compact Definition: Trying Again.” O’Reilly Radar, December 10, 2006. Retrieved from http://radar.oreilly.com/2006/12/web-20-compactdefinition-tryi.html.

Papo, W. (2001). Integration of educational media in higher education large classes. Educational Media International, 38(2/3), 95-99.

Paraskevas, A. \& Wickens, E. (2003). Andragogy and the Socratic method: The adult learner perspective. Journal of Hospitality, Leisure, Sport \& Tourism Education, 2(2), 4-14.

Persichitte, K. (2013). Leadership for educational technology contexts in tumultuous higher education seas. Techtrends: Linking Research \& Practice To Improve Learning, 57(5), 14-17.

Pew, S. (2007). Andragogy and pedagogy as foundational theory for student motivation in higher education. InSight: A Journal of Scholarly Teaching, 2(1), 14-25.

Piaget, J. (1965). The stages of the intellectual development of the child. Educational psychology in context: Readings for future teachers, 98-106.

Plageman, P. (2011). Educator, planner and advocate: Higher education for adults in the new millennium. Adult Learning, 22(2), 32-36.

Radford, A. (2011). Learning at a distance: Undergraduate enrollment in distance education courses and degree programs. Retrieved from http://nces.ed.gov/ 
pubs2012/2012154.pdf

Redmond, P. (2011). From face-to-face teaching to online teaching: Pedagogical transitions. In Proceedings ASCILITE 2011: 28th Annual Conference of the Australasian Society for Computers in Learning in Tertiary Education: Changing Demands, Changing Directions (pp. 1050-1060). Australasian Society for Computers in Learning in Tertiary Education (ASCILITE).

Renes, S. \& Strange, A. (2011). Using technology to enhance higher education. Innovative Higher Education, 36(3), 203-213.

Rodrigues, K. J. (2012). It does matter how we teach math. Journal of Adult Education, 41(1), 29-33.

Rosenbaum, P. E. L. (2012). E-Learning. A study of students' attitudes and learning outcome when using blended learning with integration of multimedia instructions. The University of Bergen.

Ross-Gordon, J. M. (2011). Research on adult learners: Supporting the needs of a student population that is no longer nontraditional. Peer Review, 13(1), 26-29.

Rutherford, C. (2010). Using online social media to support preservice student engagement. Journal of Online Learning and Teaching, Retrieved from http://jolt. merlot.org/vol6no4/rutherford 1210.pdf

Samaroo, S., Cooper, E. \& Green, T. (2013). Pedandragogy: A way forward to selfengaged learning. New Horizons in Adult Education and Human Resource Development, 25(3), 76-90.

Scanlon, L. (2009). Identifying supporters and distracters in the segmented world of the adult learner. Studies in Continuing Education, 31(1), 29-43.

Snyder, T. D. \& Dillow, S. A. (2012). Digest of education statistics 2011. National Center for Education Statistics.

Strong, R., Harder, A. \& Carter, H. (2010). Agricultural extension agents' perceptions of effective teaching strategies for adult learners in the master beef producer program.Journal of Extension, 48(3), 1-7.

Taylor, B. \& Kroth, M. (2009a). Andragogy's transition into the future: Meta-analysis of andragogy and its search for a measurable instrument. Journal of Adult Education, 38(1), 1-11.

Taylor, B. \& Kroth, M. (2009b). A single conversation with a wise man is better than ten years of study: A model for testing methodologies for pedagogy or andragogy. Journal of the Scholarship of Teaching and Learning, 9(2), 42-56. 
Taylor, M. L. (2006). Generation NeXt comes to college: 2006 updates and emerging issues. A collection of papers on self-study and institutional improvement, 2(2), 48-55.

Veletsianos, G. (2011). Designing opportunities for transformation with emerging technologies. Educational Technology, 51(2), 41.

Victor, W. (2004). Full time adult credential students' instructional preferences at California State University, Long Beach: pedagogy or andragogy?. Journal of Zhejiang University, 5(3), 365-370.

Wagner, N., Hassanein, K. \& Head, M. (2008). Who is responsible for e-learning success in higher education? A stakeholders' analysis. Retrieved from http:// www.ifets.info/journals/11 3/3.pdf

Watson, W. \& Watson, S. (2013). Exploding the ivory tower: Systemic change for higher education. Techtrends: Linking Research \& Practice To Improve Learning, 57(5), 42-46.

Woodbridge, J. (2004). Technology integration as a transforming teaching strategy. Retrieved from http://www.techlearning.com/story/showArticle. ihtml?articlelD $=17701367$

Yadav, S. (2006, August 25). Facebook - the complete biography. Retrieved from http:// mashable.com/2006/08/25/facebook-profile/

Yannuzzi, T. J. (2009). Teaching the person students become: New challenges in continuing adult and professional education. The Journal of Continuing Higher Education, 57(3), 159-167.

Zusman, A. (2005). Challenges facing higher education in the twenty-first century. American Higher Education in the Twenty-First Century: Social, Political, and Economic Challenges, 2, 115-160. 